\title{
Ultrastructural Studies of the Mode of Penetration by Phoma macdonaldii in Sunflower Seedlings
}

\author{
A. Roustaee, G. Dechamp-Guillaume, B. Gelie, C. Savy, R. Dargent, and G. Barrault
}

\begin{abstract}
First, second, and sixth authors: Laboratoire de Biotechnologie et Amélioration des Plantes, Ecole Nationale Supérieure Agronomique de Toulouse, Avenue de l'Agrobiopole, Auzeville-Tolosane, BP 107, F-31326 Castanet-Tolosan Cedex, France; fourth and fifth authors: Equipe de Mycologie Végétale, UMR-CNRS 5546 Université Paul Sabatier, 24 chemin de Borde Rouge, BP 17, Auzeville-Tolosane, F31326 Castanet-Tolosan Cedex, France; third author: Unité de Science du Sol, INRA, Centre de Recherche de Versailles, Route de SaintCyr, F-78026 Versailles Cedex, France.
\end{abstract}

Accepted for publication 4 May 2000.

\begin{abstract}
Roustaee, A., Dechamp-Guillaume, G., Gelie, B., Savy, C., Dargent, R., and Barrault, G. 2000. Ultrastructural studies of the mode of penetration by Phoma macdonaldii in sunflower seedlings. Phytopathology 90:915-920.

An ultrastructural investigation of the artificial inoculation of sunflower with Phoma macdonaldii conidia was undertaken using light, scanning, and transmission electron microscopy to elucidate the hostparasite relationship. The behavior of the conidia deposited on the cotyledon petiole was investigated at various time intervals after inoculation. Conidia adhesion and germination were observed first. The cotyledon

able thickness. At the time of penetration, the host cuticle was perforated mechanically. The cuticle was slightly depressed and no enzymatic alteration could be observed. The fungus did not form appressoria on the surface of the host tissues but developed an infection peg. As soon as the cuticle barrier was crossed, the fungus rapidly colonized the host parietal layer. In a first step, the plasmalemma of the host cell appeared to be stuck against the cell wall. As soon as the fungus passed through the epidermal cell wall to reach the host cytoplasm, the plasmalemma was disrupted, and the subsequent rapid breakdown of cell integrity favored the colonization of the tissues by the pathogen.
\end{abstract} petiole was invaded by the fungus directly through the cuticle and via stomata. Externally, the spore and germ tube were covered with a mucilaginous polysaccharide sheath of a cotton-like appearance and of vari-
Additional keywords: black stem, Helianthus annuus, host-pathogen interactions, subcuticular hyphae.
The black stem disease of sunflower (Helianthus annuus) is caused by Phoma macdonaldii (8) whose teleomorph is Leptosphaeria lindquistii (18). It has been reported in many European countries (Yugoslavia, Italy, Bulgaria, Romania) (2), Iran (33), Pakistan (44), China (24), Australia and the United States (2). Since 1990, the disease has been expanding steadily and is now recognized as one of the most serious diseases of sunflower in France (40). The disease is mainly characterized by the appearance of black spots on the stem around the petiole insertion point. Coalescing spots at the base of the stem develop into a wide black sleeve (40), and black maculae surround the back of the flower head. Premature ripening results in yield losses of 10 to $30 \%$ (39), decreased oil content (34), and decreased thousand seed weight (11). The disease can also cause early plant death $(45,16)$. The symptoms of black stem disease of sunflower have been described by various authors, but the histological and ultrastructural aspects of the infection of sunflower by $P$. macdonaldii have not been documented.

Fungal pathogen entry into plants may proceed through direct penetration via enzyme and toxin effects or mechanical pressure or indirectly through wounds or natural openings such as lenticels or stomata (25). The different tissues of the host (cotyledon petiole, leaf petiole, leaf lamina, stem, etc.) may be penetrated differently by the same fungus. Each species of fungal pathogen may display different modes of penetration under different conditions (25). In the present study, an ultrastructural investigation of the artificial inoculation of the cotyledon petiole

Corresponding author: G. Barrault; E-mail address: barrault@ensat.fr

Publication no. P-2000-0626-01R

(c) 2000 The American Phytopathological Society of sunflower by $P$. macdonaldii conidia was undertaken to elucidate the host-parasite relationship.

\section{MATERIALS AND METHODS}

Plant material. Seeds of a susceptible sunflower hybrid (Santiago) were disinfected for $5 \mathrm{~min}$ in a $0.5 \%$ sodium hypochlorite solution, then rinsed three times in sterile distilled water. They were sown regularly at a depth of $2 \mathrm{~cm}$ in $40 \times 30 \times 25-\mathrm{cm}$ plastic containers filled with vermiculite. Plants were raised in a growth chamber regulated at $24 \pm 1{ }^{\circ} \mathrm{C}$ (14-h illuminated period) and $17 \pm$ $1{ }^{\circ} \mathrm{C}$ (10-h dark period), and 75 to $85 \%$ relative humidity. The light intensity during the illuminated period was $200 \mu \mathrm{E} \mathrm{m} \mathrm{m}^{-2} \mathrm{~s}^{-1}$, provided by SON-T AGRO 400 lamps (Philips, Eindhoven, Netherlands). Each container was watered every 3 days with $500 \mathrm{ml}$ of water that contained $1 \mathrm{ml}$ of a nutrient solution (N-P-k, 6-3-6, and micronutrients [Substral, Boulogne-Billancourt, France].

Fungal isolate. A single conidial isolate of $P$. macdonaldii isolated from naturally infected plants collected in the southwest of France was used. The pathological and physiological characteristics of this isolate, which is one of the most aggressive isolates of the pathogen (42), remained constant with time, using the method of conservation described by Arabi et al. (4) for Drechslera teres. This method has proven to be efficient for the conservation of P. macdonaldii isolates since 1996.

Artificial inoculation. The pathogen was incubated on a potato dextrose agar (PDA) medium at $25 \pm 1^{\circ} \mathrm{C}$ in the light $\left(37 \mu \mathrm{E} \mathrm{m}^{-2} \mathrm{~s}^{-1}\right)$. After 10 days of incubation, the addition of sterile distilled water to the surface of the culture followed by mechanical stirring allowed a conidial suspension to be obtained. The suspension concentration was adjusted to $10^{6}$ conidia per $\mathrm{ml}$. Using a micropipette, $20 \mu \mathrm{l}$ of spore suspension were introduced into the pit 
formed by the cotyledon petiole and the epicotyl of 12-day-old sunflower seedlings (first pair of developed leaves, stages 1 to 2 [31]). A microdrop of sterile distilled water was used on the control plants. After inoculation, the containers in which the plants were grown were covered with a polyethylene bag to promote pathogen development. Observations of five samples were carried out at different time intervals after inoculation: 12, 16, 20, and $36 \mathrm{~h}$.

Light Microscopy. The petiole of the cotyledon was cut into pieces of approximately $5 \mathrm{~mm}^{2}$. The upper epidermis of the cotyledon petioles (seat of inoculation) was then peeled. The samples were stained with lactophenol-cotton blue and rinsed in lactophenol for $10 \mathrm{~min}$. The sections were mounted in distilled water and examined under a light microscope (Leica, Rueil-Malmaison, France).

Scanning electron microscopy. Fresh samples of sunflower seedlings cotyledon petioles were prepared by the cryopreservation technique. Each sample was mounted with kaolin on the stub of a Hexland CT1500 CryoTrans system (Oxford Instruments Ltd., Eynsham, England) and plunged into nitrogen slush at $-210^{\circ} \mathrm{C}$. After eventual fracturing, specimens were transferred from an evacuated pre-chamber to the microscope stage, which was cooled by nitrogen gas at $-160^{\circ} \mathrm{C}$. Surface frost was sublimed by raising the stage temperature and keeping it at $-80^{\circ} \mathrm{C}$ for $5 \mathrm{~min}$. The specimen was withdrawn and put back in the prechamber, where it was sputter-coated with gold then transferred back to the microscope stage at $-160^{\circ} \mathrm{C}$. Micrographs were obtained at $10 \mathrm{kV}$ using a $525 \mathrm{M}$ scanning electron microscope (Philips).
Transmission electron microscopy. The cotyledon petiole was cut into pieces of approximately $3 \mathrm{~mm}^{2}$ for examination by transmission electron microscopy. Samples were fixed with $2.5 \%$ glutaraldehyde in $0.05 \mathrm{M}$ phosphate buffer, $\mathrm{pH} 7.2$, for $2 \mathrm{~h}$ at room temperature.

Material was postfixed in $2 \%$ osmium tetroxide in the same buffer for $2 \mathrm{~h}$ at $20^{\circ} \mathrm{C}$ before being dehydrated in a graded ethanol series. Preparations were embedded in Spurr's epoxy resin (46).

Ultrathin sections (100 nm thick) were cut on a Reichert OMU3 microtome (Leica) and collected on gold grids. Sections were stained for $10 \mathrm{~min}$ with uranyl acetate and for $5 \mathrm{~min}$ with lead citrate for examination at room temperature. Sections were examined on a 301 electron microscope at $80 \mathrm{kV}$ (Philips).

Cytochemical techniques. Cytochemical detection of polysaccharides was performed by PATAg labeling (periodic acid, thiocarbohydrazide, silver proteinate) according to Dargent and TouzéSoulet (13). The specificity of the reactions was assessed on control sections without thiocarbohydrazide $(\mathrm{TCH})$ treatment.

\section{RESULTS}

Light Microscopy. Light microscopy (LM) observations of the fungus in sunflower cotyledon petioles are presented in Figure 1. Sixteen hours after inoculation, most spores with a $4 \pm 0.5 \mu \mathrm{m}$ diameter had germinated (Fig. 1A). Germination was first accompanied by the formation of a filament constituted of $6 \pm 2 \mu \mathrm{m}$-long

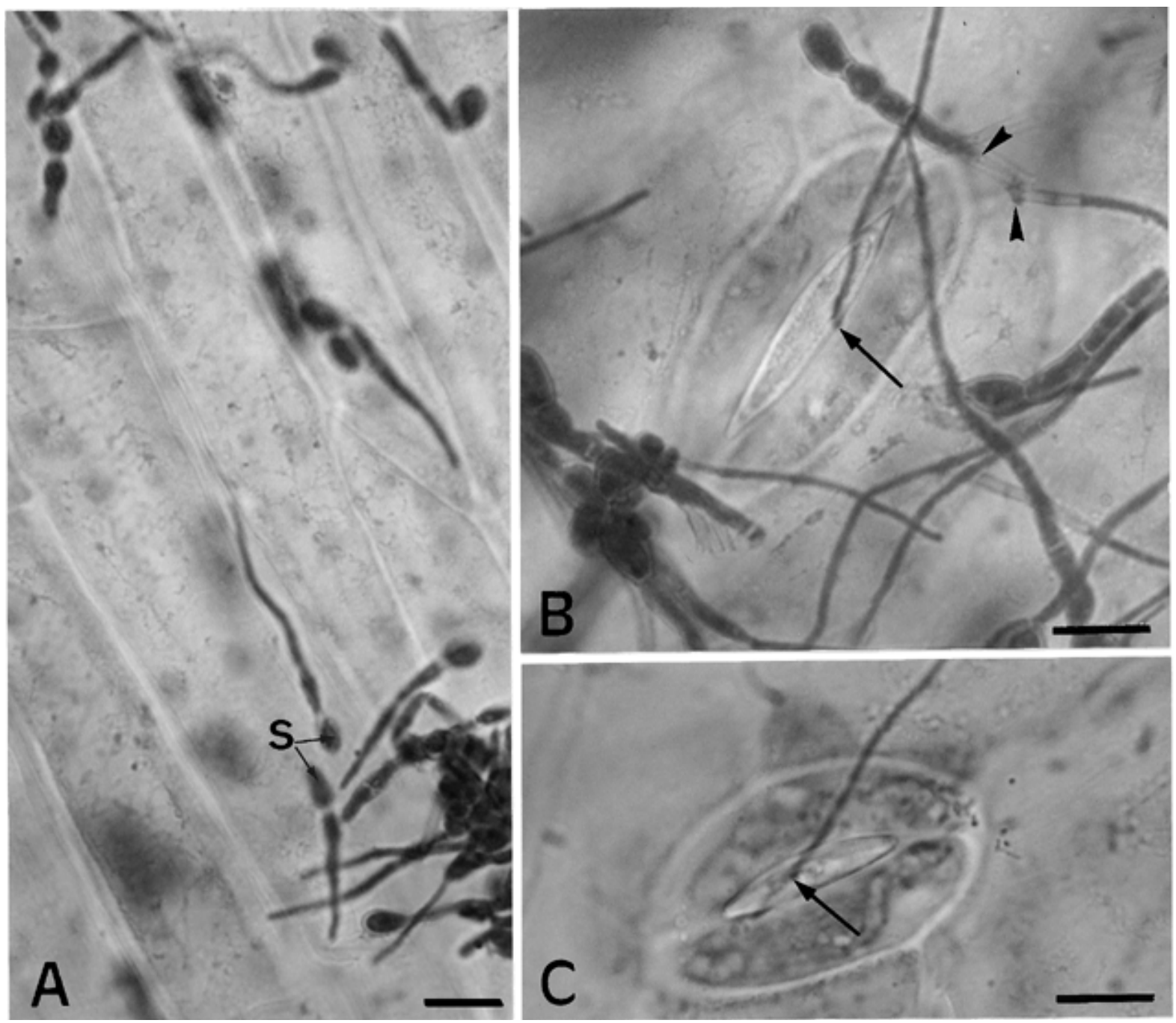

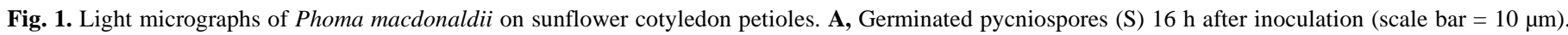

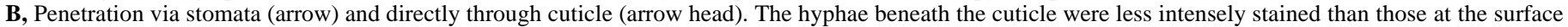
(arrow head) $($ scale bar $=10 \mu \mathrm{m})$. C, Penetration via stomata (arrow): a hypha passing through the stomatal opening $(\mathrm{scale}$ bar $=10 \mu \mathrm{m})$. 
cells with the same diameter as the spores. Germ tubes eventually reached a $1 \pm 0.3 \mu \mathrm{m}$ diameter and did not form any appressoria at the surface of the tissues. Penetration proceeded either directly through the cuticle or through the stomata (Fig. 1B and C). The hypha at the surface of the host tissues was intensely stained by cotton blue; in contrast, after penetration, the mycelium color was lighter (Fig. 1B).

Scanning electron microscopy. Twelve hours after inoculation, some of the spores with a $4 \pm 0.5 \mathrm{~mm}$ diameter gave rise to a variable-length germ tube (not exceeding $7 \mu \mathrm{m}$; Fig. 2A and B). Twenty hours after inoculation, most of the spores had germinated to give rise to short, unbranched, and creeping tubes developing into a mycelial tapetum (Fig. 2C). The surface of the cuticle and epidermal cells in contact with the germ tube did not appear to be altered, and no adhesive structure was observed. However, in the presence of a high inoculum density, spore germination resulted in the development of aerial hyphae (Fig. 2D, arrows).

After $24 \mathrm{~h}$, the external hyphae developed by the fungus on the surface of the host tissues were $1 \mu \mathrm{m}$ in diameter, a measurement comparable to those observed in LM. From $36 \mathrm{~h}$ after inoculation, the fungus was observed within the host cell wall as well as inside the epidermal cells whose cytoplasmic volume was gradually colonized (Fig. 2E).

Transmission Electron Microscopy. Between 36 and $48 \mathrm{~h}$ after inoculation, transverse sections of sunflower cotyledon petioles corresponded to the relatively important development of the fungus externally, as well as inside the host tissues (Fig. 3A). Externally, the spores observed were characterized, after PATAg staining, by a uniform wall that was weakly contrasted to electrons. The $0.3-\mu m$-thick wall was limited, on the outside, by a cotton-like mucilaginous sheath of variable thickness. The oftenretracted cytoplasmic content in every case was highly vacuolated (Fig. 3A). Spore germination gave rise to constricted, septate filaments, whose length did not exceed $5.6 \mu \mathrm{m}$; the wall was uniform and limited by an external mucilaginous layer identical to the spore wall. After double staining with uranyl acetate and lead citrate, these cells displayed an electron-dense, little-vacuolated cytoplasm, with various endomembrane systems. However, at the interface with the host epidermis, the mucilaginous sheath was thinner or invisible. At the point of contact with the host cell wall, no structural alteration was visible (Fig. 3B). Pathogen penetration was characterized by the mechanical perforation of the host wall. The cuticle was slightly collapsed, and no enzymatic alteration was observed. The fungus developed an infection peg and, as soon as the cuticular barrier was crossed, rapidly colonized the host parietal layer. Moreover, at the level of the constriction, a septum was formed in every case (Fig. 3C).

The fungal pathogen thus was composed of a septate hypha with cells with an average length of $7 \mu \mathrm{m}$. After PATAg staining, the nearly electron-transparent wall was devoid of any mucilaginous sheath. The cytoplasm of each pathogen cell was electron-dense, contained various endomembrane systems, and, at the

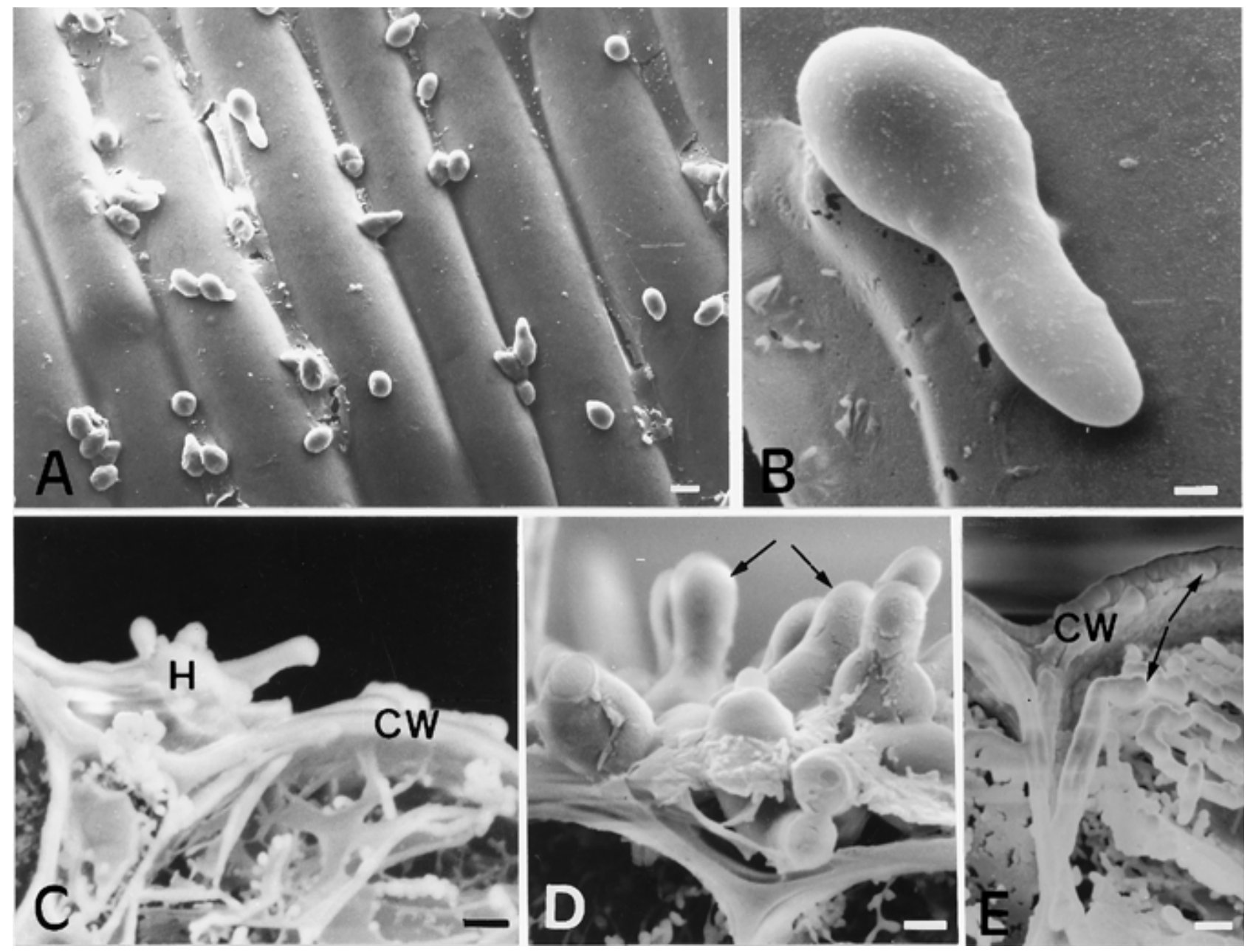

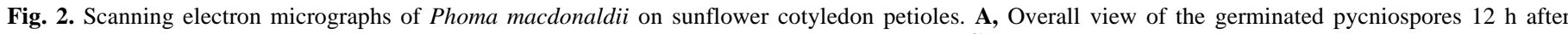

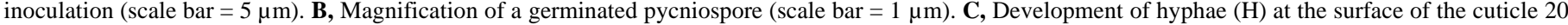

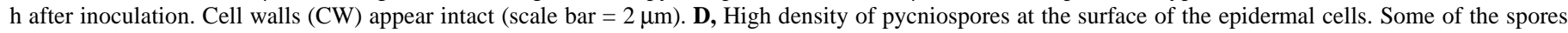

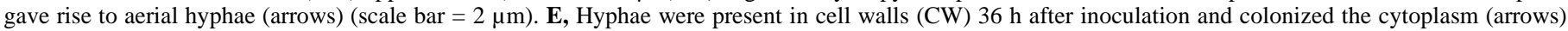
(scale bar $=2 \mu \mathrm{m}$ ). 

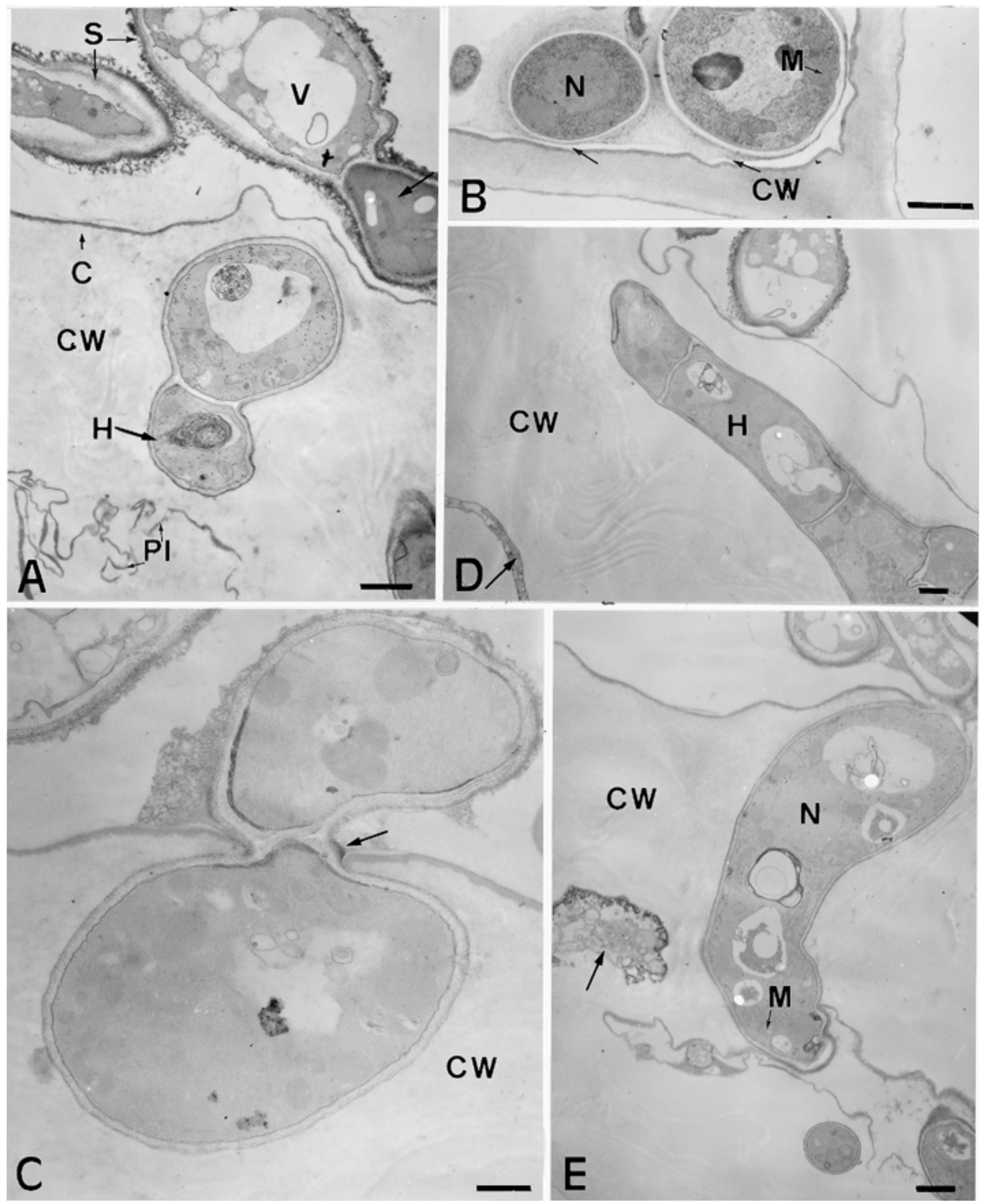

Fig. 3. Transmission electron micrographs of Phoma macdonaldii on sunflower cotyledon petioles. A, Germinating and highly vacuolated (V) Phoma spore (S) at the surface of the cuticle $(\mathrm{C})$. The germ tube was richer (darker) in cytoplasm (arrow). The external electron-dense mucilaginous layer present on the germinating spores was absent on the hyphae $(\mathrm{H})$ observed within the host cell wall $(\mathrm{CW})$. The host plasmalemma was altered $(\mathrm{scale}$ bar $=1 \mu \mathrm{m})$. B, Transverse section of hyphae at the cuticle surface after double staining with uranyl acetate and lead citrate. Endomembrane systems shown: nucleus (N), and mitochondria (M). The mucilaginous substance at the points of contact with the cuticle (arrows) was thinner or even disappeared (scale bar $=1 \mu \mathrm{m}$ ). C, Direct penetration through the cuticle without appressoria formation. Hyphae penetrated the cell wall by mechanical pressure with formation of an infection peg (arrow). After penetration into the cell wall $(\mathrm{CW})$ the hyphae were devoid of mucilage (scale bar $=0.5 \mu \mathrm{m})$. D, Expanding septate hyphae $(\mathrm{H})$ within the cell wall $(\mathrm{CW})$ beneath the cuticle. Host cytoplasm and plasmalemma (arrow) appeared to be intact (scale bar $=1 \mu \mathrm{m}$ ). E, Endomembrane systems shown in hyphae: nucleus $(\mathrm{N})$ and mitochondria $(\mathrm{M})$. The hyphae present within the cell wall $(\mathrm{CW})$ eventually reached the host cytoplasm, causing structural disorganization of the host cell (arrow) $(\mathrm{scale}$ bar $=1 \mu \mathrm{m})$. 
young stage, was little vacuolated (Fig. 3D). In a first step, the host plasmalemma was stuck against the host cell wall (Fig. 3E). As soon as the fungus passed through the epidermal cell wall to reach the host cytoplasm, the plasmalemma was disrupted, and the subsequent rapid breakdown of cell integrity favored the colonization of the tissues by the pathogen (Fig. 3E).

\section{DISCUSSION}

The symptoms of black stem have been described by various authors, but the histological and ultrastructural aspects of the infection of sunflower cotyledon petiole by $P$. macdonaldii have not been documented.

The ultrastructural investigation of the artificial inoculation of sunflower with $P$. macdonaldii conidia showed the occurrence of spore adhesion, germination, mucilage production, and direct penetration through the cuticle or stomata without appressorium formation. The present study also reports the presence of subcuticular hyphae in cotyledon petioles of sunflower infected with $P$. macdonaldii conidia.

Fungal adhesion to the host surface is an essential prepenetration process that determines the success of infection and disease development (25). Germinating conidia of P. macdonaldii and their germ tubes appeared to be attached to the sunflower cotyledon surface by the mucilaginous sheath covering the hyphae and conidia. Some fungal species produce mucilage (polysaccharides, glycoproteins, hexosamine polymers and xylans) to ensure close contact with the host $(25,30,32)$. According to Gold and Mendgen (19), the role of fungal exudates appears to be multiple. These roles include attachment to the plant surface, sealing up of the penetration site, protection of appressoria against desiccation and other limiting environmental factors, and a reservoir for "penetrating enzymes." Staining by PATAg led to the characterization of this mucilaginous substance in $P$. macdonaldii as a polysaccharide. Such mucilaginous exudates had been reported for $P$. linguam by Abadie and Boudart (1). Other fungi closely related to $P$. macdonaldii also produce such exudates: Ascochyta rabiei (23), A. fabae (35), Phyllosticta amplicida (27), and Phomopsis phaseoli (29). For some fungal pathogens, such as Colletotrichum graminicola (38), Verticillium alboatrum (tomato roots), and Fusarium oxysporum f. sp. lycopersici, it was suggested that this mucilaginous substance also contain wall-degrading enzymes (7). Pascholati et al. (38) reported that Erysiphe graminis conidia release a liquid with esterase activity that partially eroded the surface of the cuticle of barley leaves. In addition to providing adhesion, these mucilages may contain substances used for recognition of the host surface.

In our study, direct penetration to cotyledon petiole tissue through the cuticle and stomata was observed without the formation of an appressorium. Penetration without appressorium was reported for other Phoma species, such as $P$. linguam (21) and $P$. narcissi on Hippeastrum leaves (43). Penetration without appressorium formation was also reported for Phomopsis longicola (Diaporthe phaseolorum) (6), Phomopsis leptostromiformis on the stem of lupins (Lupinus angustifolius) (50), and Septoria apiicola (17). In contrast, appressorium formation was observed in other fungi closely related to Phoma sp., such as Phomopsis helianthi (36), Phoma exigua (14), Ascochyta pisi (22), A. fabae (35), and A. rabiei $(23,37)$. Different species of Phoma can infect plants with or without appressorium formation. The behavior of the fungus could be different on other parts of the plant, such as the leaf petiole or base of the stem, where pathogen penetration might be accompanied by appressoria formation. The formation of appressorium is known to depend on different factors, such as epicuticular waxes, rigidity, and surface hardness (23).

There are several types of natural openings in plants that are relatively unprotected and, therefore, vulnerable to penetration by fungal hyphae. Stomata are probably the most common route for pathogen entry (25). The stomata on the surface of the cotyledon petiole of sunflower may facilitate fungal pathogen penetration. Penetration via stomata in the cotyledon petiole of sunflower was observed for $P$. macdonaldii. This route of penetration has been reported for other pathogenic fungi, such as Leptosphaeria maculans (P. linguam) (1,20), P. exigua var. linicola (14), Ascochyta pisi (22), Phomopsis phaseoli (29), Septoria tritici (12), and S. apicola (17).

The cuticle is multilayered and separated from the plant cell wall by pectic compounds. Fungal pathogens encounter this outer layer first and usually penetrate by mechanical force (25) or through the effects of degrading enzymes, such as cutinase in the case of $F$. solani f. sp. pisi (51). Apparently, in P. macdonaldii, the infection peg breaks the cuticle by mechanical pressure. Such a mode of penetration has been reported for Rhizoctonia solani in bean hypocotyls (26). Direct penetration has also been reported for other fungi such as Phomopsis scabra on sycamore leaves (3), Colletotrichum gloeosporoides (15), C. lagenarium (9), and Fusarium spp. (28). The involvement of enzymes has been reported for $P$. linguam (pectinolyases and hemicellulases) (10).

Formation of subcuticular hyphae is not a phenomenon currently observed in fungal plant pathogens and, thus, might be considered an interesting feature of $P$. macdonaldii behavior on the cotyledon petiole of sunflower. As far as we know, the occurrence of subcuticular hyphae has not been reported in other species of Phoma. However, their presence after penetration has been reported for a number of plant pathogens. Rhynchosporium secalis (5), Venturia inaequalis (41), Botryosphaeria vaccini (49), Alternaria brassicae (48), and Phomopsis leptostromiformis (50) form such hyphae before further colonization of tissues. All of these pathogens have a relatively short latent period, except for Phomopsis leptostromiformis. The short latent period of $P$. macdonaldii (approximately 24 to $36 \mathrm{~h}$ on a susceptible variety of sunflower), thus, might be accounted for in terms of the formation of subcuticular hyphae.

Further histopathological studies of the mode of penetration and tissue colonization at different parts of sunflower, such as the base of the stem, leaf petiole, leaf lamina, or back of the flower head, are necessary to elucidate the Phoma-sunflower interactions, using both tolerant and susceptible genotypes. The role of the $P$. macdonaldii toxin (zinniol) (47) in the pathogenesis and infection process should also be investigated.

\section{LITERATURE CITED}

1. Abadie, M., and Boudart, G. 1982. Etude cytologique et ultrastructurale de la nécrose des crucifèries due à Leptosphaeria maculans forme conidienne Phoma linguam. Ann. Scien. Natur., Botan. 13:53-72.

2. Acimovic, M. 1984. Sunflower diseases in Europe, the United States and Australia, 1981-1983. Helia 7:45-54.

3. Ammon, V., and Vann, S. R. 1994. Scanning electron microscopy of sycamore pathogens on inoculated leaves. Tech. Bull. Miss. Agric. For. Exp. Station 196:6.

4. Arabi, M. I., Barrault, G., Sarrafi, A., and Albertini, L. 1992. Variation in the resistance of barley cultivars and in the pathogenicity of Drechslera teres f. sp. maculata and D. teres f. sp. teres isolates from France. Plant Pathol. 41:180-186.

5. Ayres, P. G., and Owen, H. 1971. Resistance of barley varieties to establishment of subcuticular mycelia by Rhynchosporium secalis. Trans. Br. Mycol. Soc. 57:233-240.

6. Baker, D. M., and Minor, H. C. 1987. Infection of immature soybean pods and seeds by Phomopsis longicolla. Can. J. Microbiol. 33:797-801.

7. Bishop, C. D., and Cooper, R. M. 1983. An ultrastructural study of root invasion in three vascular wilt diseases. Physiol. Plant Pathol. 22:15-27.

8. Boerema, G. H. 1970. Additional notes on Phoma herbarum. Persoonia $6: 15-48$.

9. Bonnen, A. M., and Hammerschmidt, R. 1989. Cutinolytic enzymes from Colletotrichum lagenarium. Physiol. Mol. Plant Pathol. 35:463-474.

10. Boudart, G. 1981. Modalités de l'attaque parasitaire des crucifères par Leptosphaeria maculans (Desm) et de Not. (f.c. Phoma linguam), agent de la nécrose du collet, déterminisme moléculaire du pouvoir pathogène. Ph.D. thesis, Université des Sciences et Techniques de Lille, Lille, France. 
11. Carson, M. L. 1991. Relationship between Phoma black stem severity and yield losses in hybrid sunflower. Plant Dis. 75:1150-1153.

12. Cohen, L., and Eyal, Z. 1993. The histology of processes associated with the infection of resistant and susceptible wheat cultivars with Septoria tritici. Plant Pathol. 42:737-743.

13. Dargent, R., and Touzé-Soulet, J. M. 1976. Sur l'ultrastructure des hyphes d'Hypomyces chlorinus Tul. cultivé en présence ou en absence de biotine. Protoplasma 89:49-71.

14. Decognet, V. 1994. Phoma exigua var. linicola, agent du mort-lin: Variabilité et mode d'infection du parasite, expression de la maladie. $\mathrm{Ph} . \mathrm{D}$. thesis, Université de Rennes, Rennes, France.

15. Dickman, M. B., Patil, S. S., and Kolattukudy, P. B. 1982. Purification and characterization and role in infection of an extracellular cutinolytic enzyme from Colletotrichum gloeosporioides on Carica papaya. Physiol. Plant Pathol. 20:333-347.

16. Donald, P. A., Venette, J. R., and Gulya, T. J. 1987. Relationship between Phoma macdonaldii and premature death of sunflower. Plant Dis. 71:466-468.

17. Donovan, A., Isaac, S., Collin, H. A., and Veltkamp, C. J. 1990. An ultrastructural study of the infection of the excised leaves of celery by Septoria apiicola, causal agent of leaf spot disease. Mycol. Res. 94:548552.

18. Emmett, R. W., and Parbery, D. G. 1975. Appressoria. Annu. Rev. Phytopath., 13:147-167.

19. Frezzi, M. J. 1968. Leptosphaeria lindquistii, forma sexual de Phoma oleracea var. helianthi-tuberosi Sacc., hongo causal de la "mancha negra del tallo" del girasol (Helianthus annuus L.), en Argentina. Patol. Veg. 5:73-80.

20. Gold, R. N., and Mendgen, K. 1984. Cytology of basidiospore germination, penetration, and early colonization of Phaseolus vulgaris by Uromyces appendiculatus var. appendiculatus. Can. J. Bot. 62:1989-2002.

21. Hammond, K. E., Lewis, B. J., and Musa, T. M. 1985. A systemic pathway in the infection of oilseed rape by Leptosphaeria maculans. Plant Pathol. 34:557-565.

22. Heath, M. C., and Wood, R. K. S. 1969. Leaf spots induced by Ascochyta pisi and Mycosphaerella pinnodes. Ann. Bot. 33:657-670.

23. Höhl, B., Pfautsch, M., and Barz, W. 1990. Histology of disease development in resistant and susceptible cultivars (Cicer arietinum L.) inoculated with spores of Ascochyta rabiei. J. Phytopathol. 129:31-45.

24. Hua, Z., and Ma, G. 1996. A review of sunflower disease research in China. Pages 754-759 in: Proc. 14th Int. Sunflower Conf. Organizing Committee of the 14th International Sunflower Conference, Beijing, China.

25. Isaac, S. 1992. Fungal-Plant Interactions. Chapman and Hall, London.

26. Kenning, L. A., and Hanchey, P. 1980. Ultrastructure of lesion formation in Rhizoctonia-infected bean hypocotyls. Phytopathology 70:998-1004.

27. Kerchung, K., and Hoch, H. C. 1995. Visualization of the extracellular matrix surrounding pycnidiospores, germlings and appressoria of Phylosticta amplicida. Mycologia 87:759-771.

28. Köller, W. 1991. The plant cuticle: A barrier to be overcome by fungal plant pathogens. Pages 219-246 in: The Fungal Spore and Disease Initiation in Plants and Animals. G.T. Cole and H. C. Hoch, eds. Plenum Press, New York.

29. Kulik, M. M. 1988. Observation by scanning electron and bright-field microscopy on the mode of penetration of soybean seedlings by Phomopsis phaseoli. Plant Dis. 72:115-118.

30. Laborda, F., and Maxwell, D. P. 1976. Ultrastructural changes in Cladosporium cucumerinum during pathogenesis. Can. J. Microbiol. 22:394-403.

31. Lancashire, P. D., Bleiholder, H., Langelüddecke, P., Stauss, R., Van Den Boom, T., and Weber, E. 1991. An uniform decimal code for growth stages of crops and weeds. Ann. Appl. Biol. 119:561-601.

32. Lazarovits, G., and Higgins, V. J. 1976. Ultrastructure of susceptible, resistant and immune reactions of tomato to races of Cladosporium fulvum. Can. J. Bot. 54:235-249.

33. Madjidieh-Ghassemi, S. 1988. Studies on some important fungal diseases of sunflower in Iran. Pages 22-23 in: Proc. 12th Int. Sunflower Conf. Orgainizing Committee of the 12th International Sunflower Conference, Novi-Sad, Yugoslavia.

34. Maric, A., Camprag, D., and Masirevic, S. 1988. Sunflower black stem (In Serbo-Croatian), Nolit, Beograd, Yugoslavia. Pages 37-45.

35. Maurin, N., Gourret, J. P., and Tivoli, B. 1993. Histopathology of the interaction between Ascochyta fabae and Vicia faba: Comparison of susceptible and resistant reactions. Agronomie 13:921-927.

36. Muntanola-Cvetkovic, M. 1989. Pathohistology of sunflower stems attacked by Diaporthe helianthi. Can. J. Bot. 67:1119-1125.

37. Pandey, B. K., Singh, U. S., and Chaube, S. H. 1987. Mode of infection of Ascochyta blight of chickpea caused by Ascochyta rabiei. J. Phytopathol. 119:88-93.

38. Pascholati, S. F., Yoshioka, H., and Kunoh, H. 1992. Preparation of the infection court by Erysiphe graminis f. sp. hordei: Cutinase is a component of the conidial exudate. Physiol. Mol. Plant Pathol. 41:53-59.

39. Penaud, A. 1996. Phoma du tournesol: Recherche des époques de contamination et mise au point de la protection fongicide. Pages 694-699 in: Proc. 14th Internat. Sunflower Conference. Orgainzing Committee of the 14th International Sunflower Conference, Beijing, China.

40. Peres, A., and Lefol, C. 1996. Phoma macdonaldii Boerema: Éléments de biologie et mise au point d'une méthode de contamination artificielle en conditions contrôlées. Pages 687-693 in: Proc. of the 14th Internat. Sunflower Conference. Beijing, China.

41. Preece, T. F. 1962. Removal of apple leaf cuticle by pectinase to reveal the mycelium of Venturia inaequalis (Cooke) Wint. Nature (Londi). 193:902-903.

42. Roustaee, A., Costes, S., Dechamp-Guillaume, G., and Barrault, G. 2000. Phenotypic variability of Leptosphaeria lindiquistii (anamorph: Phoma macdonaldii), a fungal pathogen of sunflower. Plant Pathol. In press.

43. Saniewska, A., and Dyki, B. 1997. Development of Phoma narcissi within tissues of Hippeastrum leaves. Phytopathol. Polonica 14:55-60.

44. Siddique-Mirza, M., Masood, A. R., and Ayub, M. 1988. Sunflower diseases in Pakistan in the period 1980 to 1987. Pages 2-25 in: Proc. 12th Inter. Sunflower Conf. Organizing Committee of the International Sunflower Conference, Novi-Sad, Yugoslavia.

45. Smolik, J. D., Walgenbach, D. D., and Carson, M. L. 1983. Initial evaluations of early dying of sunflower in South Dakota. Pages 24-25 in: Proc. Sunflower Res. Workshop, Fargo.

46. Spurr, A. R. 1969. A low-viscosity epoxy resin embedding medium for electron microscopy. J. Ultrastruct. Res. 26:31-43.

47. Sugarawa, F., and Strobel, G. 1986. Zinniol, a phytotoxin, is produced by Phoma macdonaldii. Plant Sci. 43:19-23.

48. Tewari, J. P. 1986. Subcuticular growth of Alternaria brassicae in rapeseed. Can. J. Bot. 64:1277-1281.

49. Weidemann, G. J., and Boone, D. M. 1984. Development of latent infections on cranberry leaves inoculated with Botryosphaeria vaccinii. Phytopathology 74:1041-1043.

50. Williamson, P. M., and Sivasithamparam, K. 1991. Formation of subcuticular coralloid hyphae by Phomopsis leptostromiformis upon latent infection of narrow-leafed lupins. Plant Dis. 75:1023-1026.

51. Woloshuck, C. P., and Kolattukudy, P. E. 1984. Cutinase induction in germinating spores of Fusarium solani f. sp. pisi. Phytopathology 74:832-841. 